\title{
Technical Performance and Economic Feasibility Assessment of A Mechanical Yam Harvester
}

\author{
C. K. Bosrotsi*, A. Addo, K. A. Dzisi, S. K. Agodzo \\ Department of Agricultural and Biosystems Engineering, KNUST, Kumasi-Ghana \\ *cbosrotsi@yahoo.com
}

\begin{abstract}
The objective of this study was to evaluate the performance of a mechanical yam harvester. The harvester was operated at average soil depth of $0.30-0.33 \mathrm{~m}$ and tuber spread values of $0.18-0.22 \mathrm{~cm}$. The tuber length varied from 0.33 to $0.38 \mathrm{~cm}$ and tuber depth of penetration also varied from 0.29 to $0.37 \mathrm{~cm}$ irrespective of yam variety. The tractor harvesting speed and field capacity values were 1.04 to $1.31 \mathrm{~m} / \mathrm{s}$ and 0.30 to 0.38 ha/h respectively. Fuel consumption and wheel slippage ranged from 9.07 to $9.75 \mathrm{l} / \mathrm{ha}$ and 2.93 to $3.79 \%$ for mound and ridged landforms respectively. Tuber damage values were $1.96 \%$ and $3.45 \%$ for ridge and mound harvesting respectively. Mechanical harvesting reduced harvesting cost by 50\%. The cost of US\$ 1500.00 for the yam harvester gave a breakeven point of about $180 \mathrm{~h}$ of use ( 64 ha of harvested land area) when used for custom services at a cost of US\$ 5.00 per $h$.
\end{abstract}

Keywords: Mechanical harvester, yam, field performance, economic feasibility.

\section{INTRODUCTION}

Yam (Dioscorea spp.) is a staple crop cultivated in parts of West Africa, Asia, India and Brazil. Globally, yams are cultivated on about five million hectares in about 47 countries in tropical and subtropical regions of the world (FAOSTAT, 2013). The majority of yams consumed worldwide are produced in West Africa with over $90 \%$ of the world's total production (Nweke, 2005). Over the past two decades, Ghana has performed creditably well by increasing yields from $68,828 \mathrm{~kg} / \mathrm{ha}$ in 1986 to $115,101 \mathrm{~kg} / \mathrm{ha}$ in 2010, probably due to the improved agronomic interventions (FAOSTAT, 2013). However, to realise the full potential of the crop and ensure sustainable production of yams in the coming years, it is critical that agronomic interventions become commensurate to mechanised interventions, especially in the area of harvesting. However, there has been no significant improvement or support in the development and adoption of mechanised methods of production (Sowley and Tiesaa, 2007).

Yam harvesting is manually done and Otoo et al. (2013) reported that out of the total manually harvested tubers, between 10-40\% are damaged from cuts during harvesting, piercing from roots of trees and poor handling of tubers. Any damage to the tuber significantly reduces its value, hence farmers have developed some level of apathy towards the use of mechanised harvesters and would prefer using manual labour, as is traditionally being practised. Itodo and Daudu (2013) reported 19\% tuber damage at harvest for a tractor-mounted yam harvester fitted with a collection unit. This perhaps has contributed to the failure of previous attempts of mechanising yam harvesting. Currently, there is no commercially available mechanical yam harvester in Ghana and the West African sub-region, notwithstanding previous research attempts (Opara, 2003; Itodo \& Daudu, 2007).

With the increasing demand for yams globally and the desire to increase production, farmers hope for an opportunity to increase their output while reducing harvesting drudgery (Akinbamowo et al., 2011). Otoo et al. (2013) proposed the need for mechanised yam harvesting to improve farmer productivity and reduce postharvest losses. Therefore, the development of a mechanical yam harvester will enhance yam tuber harvesting in a timely and safe manner, and reduce the level of tuber damage and losses. The objective of this study was to evaluate the performance of a newly-developed mechanical yam harvester. 


\section{MATERIALS AND METHODS}

\section{Study Area}

The study was undertaken at the research field of the Ejura College of Agriculture located at Ejura in the Ashanti Region of Ghana. Ejura is located in a major yam growing area, and the relatively flat nature of the land lends itself to mechanisation, thus it accounts for a large numbers of tractors that are employed by most farmers in the area( Aikins \& Haruna, 2012).

\section{Land Preparation and Yam Varieties}

One hectare of field was initially prepared using a disc plough as a primary tillage implement followed by a harrow as a secondary tillage implement. The field was divided into two equal parts mounds were constructed on one part and ridges on the other (Figure 1). The spacing was $1.2 \mathrm{~m} \times 1.0$ $\mathrm{m}$ with an average height of $0.4 \mathrm{~m}$. Lili and Puna varieties of yam were planted in rows on both ridged and mound landforms. The yam was coppiced and the fields were cleared of weeds prior to harvesting.

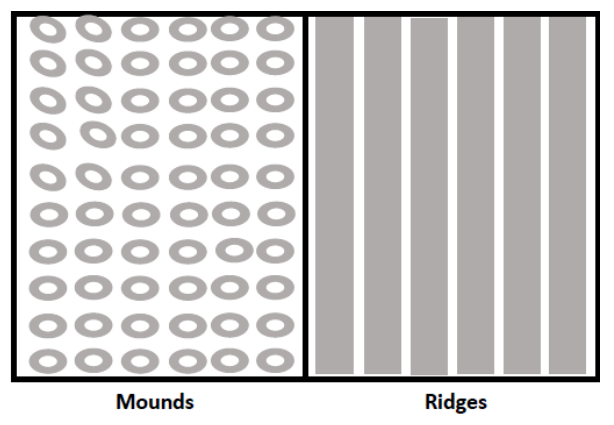

Figure 1. Field layout for the study

\section{Description of the Mechanical Yam Harvester}

Figure 2 shows the mechanical yam harvester. It has top and lower links for attachment to the threepoint linkage of the tractor. A trapezoidal digging blade, bolted to the two vertical supports, dig and lifts the yam tubers from the soil during harvesting. The shaker rods are located at the back of the blade for separation of soil from the yam tubers as the tractor moves ahead. The overall height of the harvester is $1.16 \mathrm{~m}$ and it has a gross weight of $105 \mathrm{~kg}$.

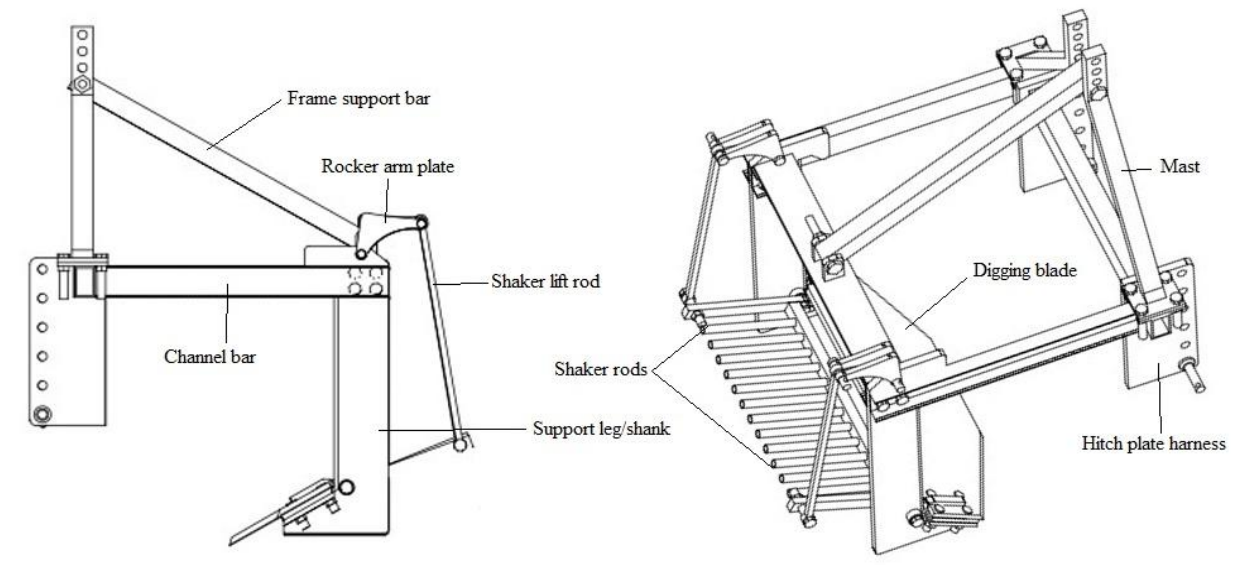

Figure 2. Schematic diagram of the mechanical yam harvester.

\section{Data Collection}

\section{Soil Sampling}

Five replicates of soil samples were randomly collected with a soil auger with $5 \mathrm{~cm}$ diameter soil core sampler and a malletat depths of $0-10,10-20,20-30$ and 30-40 cm while bulk density were determined at depths of 0-20 and 20-40 $\mathrm{cm}$ before and after harvesting using a. Samples of the soil were oven dried at a temperature of $105^{\circ} \mathrm{C}$ for $24 \mathrm{~h}$ for soil moisture determination as recommended 
by Black (1965).Penetrometer tests were carried witha penetrologger (Eijkelkamp Soil and Water, model 0615SA Giesbeek, The Netherlands) with a $60^{\circ}$ circular steel cone and a base area of $100 \mathrm{~mm}^{2}$ at depths of 0-10, 10-20, 20-30, and 30-40 cm before and after harvest.

\section{Yam Agronomic Measurement}

Agronomic data including depth of tuber penetration, tuber length and tuber spread (head to tip) under both mound and ridged land preparation methods were collected on 25 yam hills for each variety. This involved digging around the mound or ridge to expose the yam tuber. Yam tuber length, depth of penetration and tuber spread were determined using a carpenter's tape measure, and tuber roundness was determined using a digital Vernier calliper. Figure 3 shows the measurement of tuber depth of penetration, tuber length and spread.

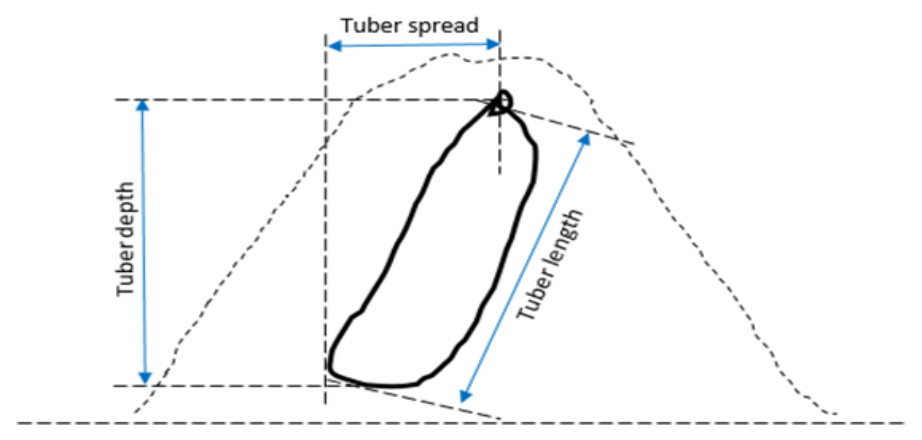

Figure 3. Yam tuber depth, spread and length measurements.

\section{Mechanical Yam Harvesting}

The mechanical yam harvester was hitched to the three point linkages of two models of agricultural tractors-a Cabrio $50 \mathrm{hp}$ Category I 4WD tractoranda $75 \mathrm{hp} \mathrm{New} \mathrm{Holland} \mathrm{Category} \mathrm{II} \mathrm{general} \mathrm{purpose}$ 2WD tractor (Figure 4). The necessary adjustments were made before the commencement of the harvesting operations.
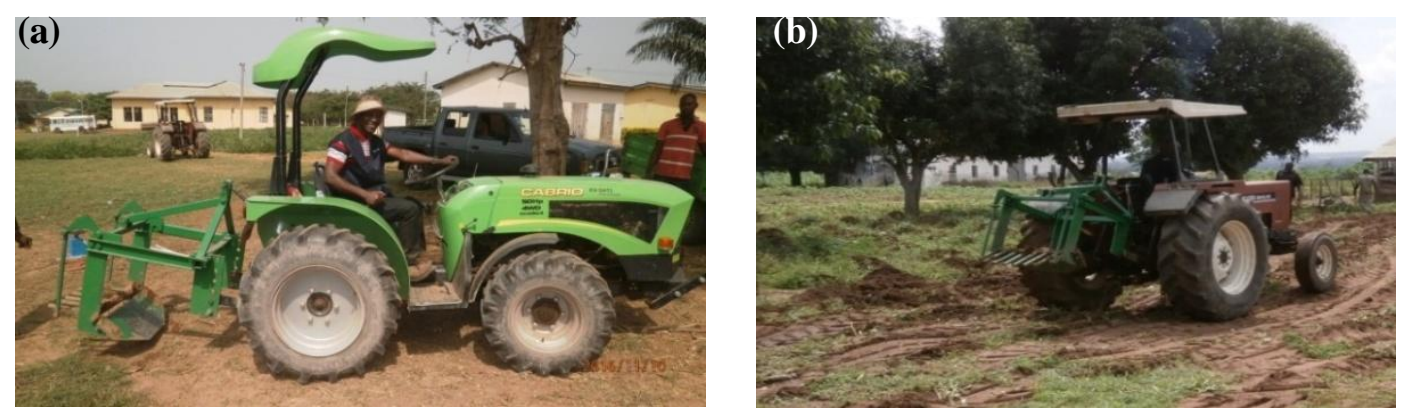

Figure 4. Harvester hitched to (a) Category I tractor (b) Category II tractor.

\section{Depth of Harvester Blade Penetration}

Depth of blade penetration after harvesting was determined using a depth measuring probe together with a measuring tape as adopted by Amponsah et al. (2014a).

\section{Yam Tuber Damage}

Yam tuber mass and damaged (broken) tubers after harvest were determined using an electronic balance. Broken or severely bruised yam tubers were separated, weighed and tuber damage calculated as a percentage of the total tuber mass for each variety.

\section{Fuel Consumption}

Measurement of fuel consumption was carried out according to the method used by Smith (1994) and Amponsah et al. (2014).

\section{Harvesting Speed and Slip Measurement}

Wheel slip was measured according to the method used by Smith (1994) and Amponsah et al. (2014). Tractor wheel slippage was then determined using Equation 1.

$$
\text { Slippage }(\%)=\left(1-\frac{\text { Speed under loading condition }(\mathrm{m} / \mathrm{s})}{\text { Speed under no loading condition }(\mathrm{m} / \mathrm{s})}\right) \times 100
$$




\section{K. Bosrotsi et al.}

\section{Harvesting field Capacity}

The field capacity was determined by recording the total time expended to harvest a given area of the field. From the effective working width of the harvester and the average speed of harvest, the field capacity was determined using Equation 2:

$$
\text { Field capacity }(\mathrm{ha} / \mathrm{h})=\frac{\text { Working width }(\mathrm{m}) \times \text { Speed }(\mathrm{m} / \mathrm{s}) \times 3600}{10000}
$$

\section{Economics of Mechanical Yam Harvesting}

The total cost of mechanical yam harvesting was determined by taking into consideration the fixed and variable cost parameters based on the recommendations and assumptions by Hunt (1983) and Hanna (2001) (Table 1).

Table 1. Assumptions and recommendations for cost calculations.

\begin{tabular}{|l|l|}
\hline Cost Parameter & Assumption \\
\hline Taxes & $0 \%$ of purchase price \\
\hline Shelter & $0.5 \%$ of purchase price \\
\hline Insurance & $0.5 \%$ of purchase price \\
\hline Repairs and maintenance & $5 \%$ of purchase price \\
\hline Lubricant cost & $15 \%$ of fuel cost \\
\hline
\end{tabular}

The expected revenue, profit and break-even cost were determined using the calculated total harvesting cost aassumed per hour based on custiom hiring service.Lindeburg (1993) and Fairhurst (2012) calculated the breakeven cost using Equation 3.

$$
\text { Breakeven cost }=\frac{\text { Total fixed cost }}{\text { Hiring cost }- \text { total variable cost }}
$$

\section{Statistical Analysis}

Descriptive statistics of means using three replicates were determined and reported for all results obtained. The statistical analysis was performed using completely randomized design with single factor analysis of variance (ANOVA) for all data and analysed with Genstat Analysis software (VSN International, 2011). Least significant differences (LSD) was carried out at 5\% level to pinpoint any differences in treatment means and also determine interactions between factors.

\section{RESULTS AND DiSCUSSIONS}

\section{Soil Condition}

Figure 5 shows the soil moisture content before and after mechanical harvesting with the yam harvester for both mound and ridged land preparation methods. Soil moisture values ranged from $11.91 \%$ d.b to $14.48 \%$ d.b. before harvesting while it varied from $11.47 \%$ d.b to $14.27 \%$ d.b after harvesting as soil depth increased from $10 \mathrm{~cm}$ to $40 \mathrm{~cm}$.

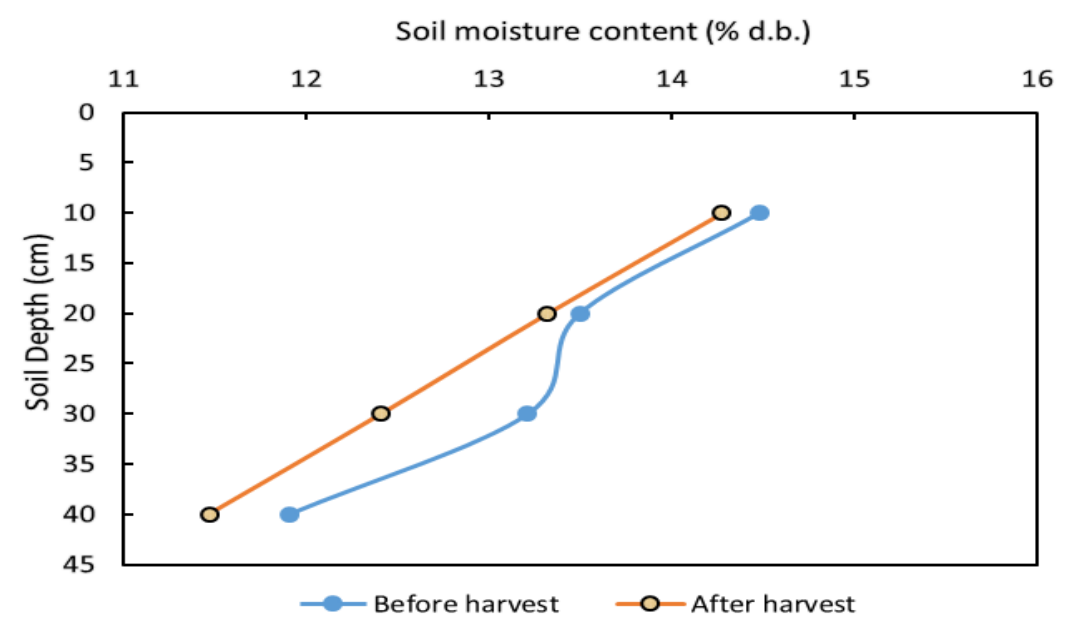

Figure 5. Soil moisture content before and after mechanical yam harvesting. 
The results show a general decreasing trend in soil moisture content with increasing soil depth from 0$40 \mathrm{~cm}$ before and after harvesting. This suggests that there was less moisture as the soil profile increase. Though soil moisture after harvesting was relatively lower than before harvesting, no significant difference $(\mathrm{p}>0.05)$ was observed. The relatively lower moisture content after harvesting could be attributed to water evaporation due to the exposure of pulverised soil after mounds or ridges have been destroyed during harvesting.

Figure 6 shows the soil bulk density before and after mechanical yam harvesting for both mounds and ridged land preparation methods. Bulk density ranged from $1.50 \mathrm{~g} / \mathrm{cm}^{3}$ to $1.62 \mathrm{~g} / \mathrm{cm}^{3}$ before harvesting while ranging from $1.55 \mathrm{~g} / \mathrm{cm}^{3}$ to $1.63 \mathrm{~g} / \mathrm{cm}^{3}$ after harvesting as soil depth increased from 10 to $40 \mathrm{~cm}$.

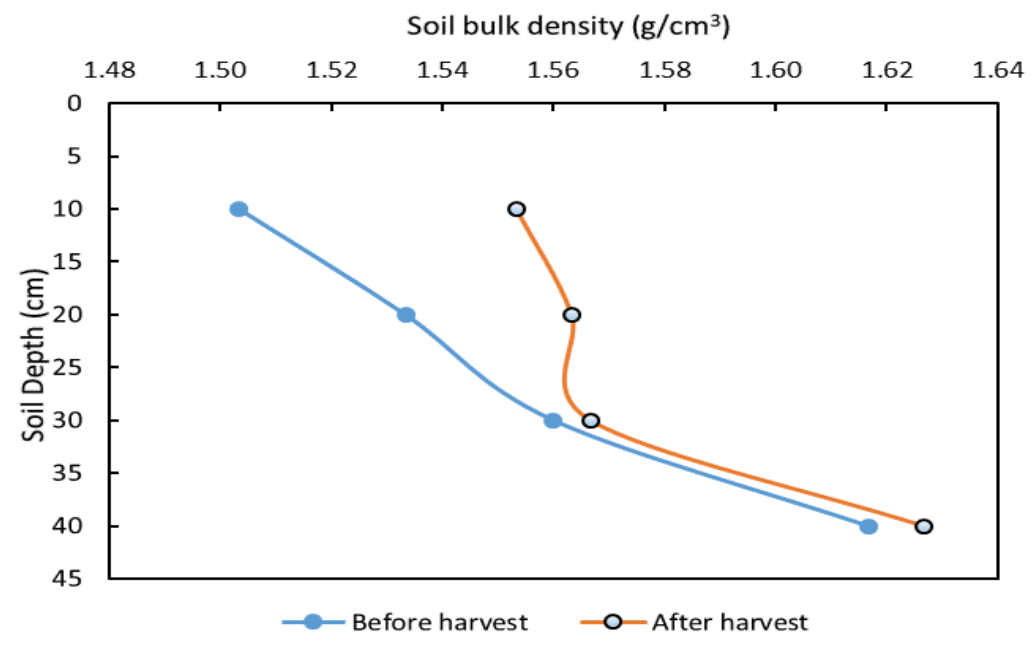

Figure 6. Soil bulk density before and after mechanical yam harvesting.

The results show a relatively greater soil bulk density after harvesting than before harvesting. This suggests that the tractor with implement might have caused some degree of compaction to the soil; though no significant difference $(\mathrm{p}>0.05)$ was observed between bulk density before and after mechanical harvesting. Results also show a generally increasing soil bulk density for both before and after harvesting with increasing soil depth (0-40), regardless of the land preparation method (mound or ridge).

The cone penetration resistance before and after mechanical yam harvesting increased with increasing soil depth is presented in Figure 7.

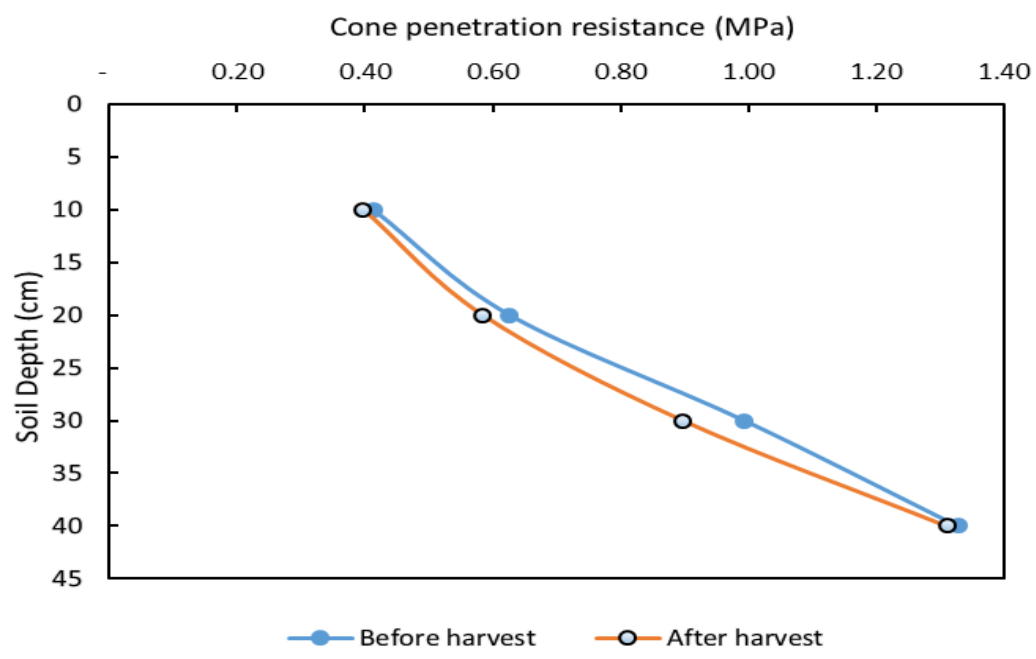

Figure 7. Cone penetration resistance before and after mechanical yam harvesting.

Cone penetration resistance ranged from 0.41 to $1.33 \mathrm{MPa}$ before harvesting but ranged between 0.40 MPa and 1.31 MPa after harvesting with increasing soil depth $(0-40 \mathrm{~cm})$ irrespective of the method of land preparation (mound or ridge). The results show a generally increasing soil strength (cone penetration resistance) with increasing soil depth from $10 \mathrm{~cm}$ to $40 \mathrm{~cm}$. Soil strength before 


\section{K. Bosrotsi et al.}

harvesting was relatively greater than after harvesting. This could be attributed to the pulverisation of soil during harvesting operation by the harvester, thereby causing a reduction in soil strength after harvesting. However, no significant difference $(\mathrm{p}>0.05)$ was observed between soil strength before and after harvesting, irrespective of the method of land preparation.

\section{Yam Agronomic Properties}

Yam tuber yield, length and spread of Lili and Pona at harvest are presented in Table 2. The mass per tuber ranged from 2.05 to $3.13 \mathrm{~kg}$ for Lili and Pona varieties respectively. Tuber length and spread ranged from 0.33 to $0.38 \mathrm{~cm}$ and 0.18 to $0.22 \mathrm{~cm}$ for Pona and Lili respectively, irrespective of the land preparation method.

Table 2. Tuber yield, length and spread for Lili and Pona yam varieties.

\begin{tabular}{|l|l|l|l|}
\hline & Lili & Pona & LSD \\
\hline Tuber yield $(\mathrm{kg})$ & 2.05 & 3.13 & 0.54 \\
\hline Tuber length $(\mathrm{cm})$ & 0.38 & 0.33 & 0.029 \\
\hline Tuber spread $(\mathrm{cm})$ & 0.22 & 0.18 & 0.036 \\
\hline
\end{tabular}

The mass per tuber value of Pona was significantly greater than that of Lili. Conversely, tuber length and spread for Pona were significantly lower than Lili. Characteristically, Pona tubers are heavier but short in length whiles Lili tubers are slender and longer but weigh less. The results also indicate that the tuber spread for both yam varieties are within the cutting width of the mechanical harvester $(0.8$ $\mathrm{m})$. Therefore, there is the less likelihood of tuber damages resulting from the harvester side supports (legs) during harvesting for Pona and Lili.

Figure 8 shows the depth of soil penetration by yam tubers and harvester blade on the mound and ridge land preparation methods.

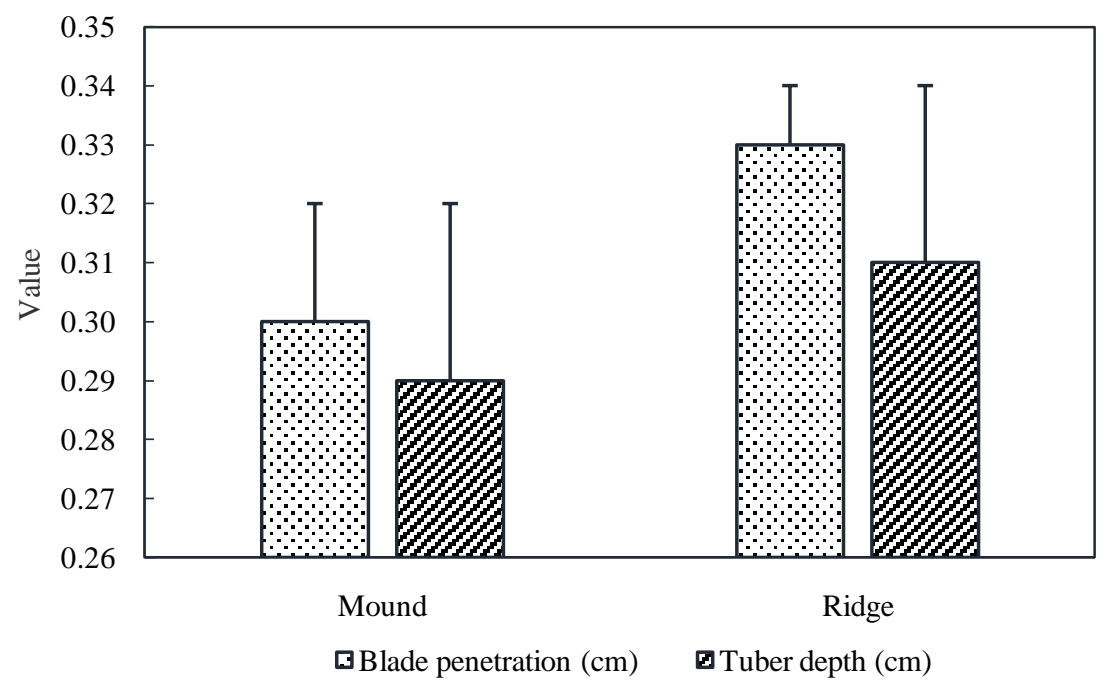

Figure 8. Yam tuber and harvester blade depth of penetration.

The mean harvester blade penetration values were $0.30 \mathrm{~m}$ and $0.33 \mathrm{~m}$ for the mound and ridge land preparations respectively. Similarly, the yam tuber depth ranged 0.29 to $0.31 \mathrm{~m}$ respectively for mound and ridged land preparations. The depth of harvester penetration on ridges was significantly greater $(p>0.05)$ than on mounds, irrespective of the yam variety. This could be attributed to the less undulating nature of the ridged landform, thus the harvester had less resistance to movement with consequent increasing depth of penetration. Similarly, the tuber penetration depth on the ridges was greater than on the mound; though no significant difference was observed. From the results, the depth of blade penetration generally was beyond the yam tuber depth. This suggests that no tuber damage would result from the blade cutting the yam tubers.

\section{Performance Evaluation}

Figure 9 shows the percentage tuber damage for mound and ridged land preparation methods during harvesting with the mechanical yam harvester. Mean tuber damage ranged from 1.96 to $3.44 \%$ for the ridged and mound land preparation methods respectively. 


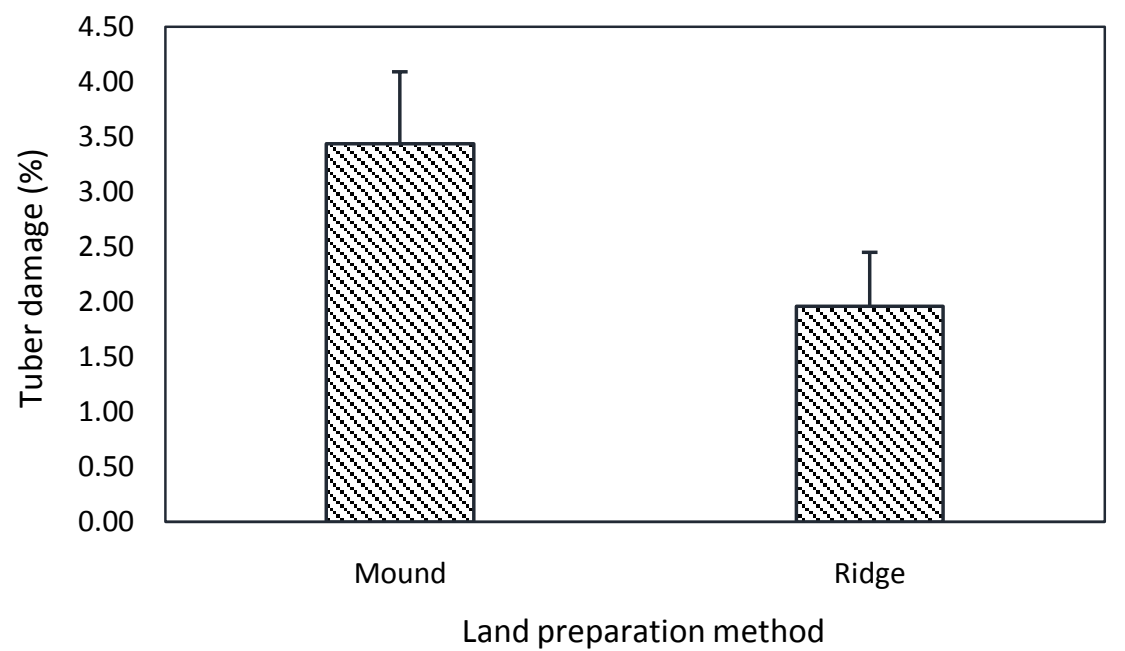

Figure 9. Percentage tuber damage experienced on mound and ridges at harvest.

The results indicate that percentage tuber damage on ridges was significantly $(p>0.05)$ lower than on the mound landform. This was because harvesting on the ridges was smoother since there was less lifting and lowering of the harvester.

Table 3 presents the technical performance evaluation results (speed, field capacity, fuel consumption and percentage wheel slip) during mechanical yam harvesting on mound and ridged land preparation methods.

Table 3. Technical performance evaluation parameters of the mechanical yam harvester during harvesting on mounds and ridges

\begin{tabular}{|l|l|l|l|l|}
\hline \multicolumn{4}{|l|}{ Evaluation Parameter } \\
\hline Landform & Speed (m/s) & Field capacity (ha/h) & Fuel consumption (1/ha) & Wheel slip (\%) \\
\hline Mound & 1.31 & 0.38 & 9.07 & 2.93 \\
\hline Ridge & 1.04 & 0.30 & 9.75 & 3.79 \\
\hline LSD & 0.128 & 0.037 & 0.394 & 0.579 \\
\hline
\end{tabular}

The results show that harvesting speed and field capacity ranged from 1.04 to $1.31 \mathrm{~m} / \mathrm{s}$ and 0.30 to $0.38 \mathrm{ha} / \mathrm{h}$ respectively for ridged and mound landforms. On the other hand, fuel consumption and tractor wheel slip ranged from 9.07 to $9.75 \mathrm{l} / \mathrm{ha}$ and 2.93 to $3.79 \%$ respectively for mound and ridged landforms. Harvesting on the mound offered greater speed of travel, and field capacity which was significantly $(\mathrm{p}>0.05)$ greater than harvesting on the ridge. This was due to the draft force encountered in the ridged landform as compared to the mounds which had intra-row space between successive mounds thus offering lower resistance to tractor movement.

From the foregoing, fuel consumption and wheel slip at harvest were significantly $(p>0.05)$ lower on the mound than on the ridged landform. This was because at higher travel speed, the tractor had enough force to overcome soil rolling resistances hence the lower wheel slip observed on the mounds. Furthermore, at a higher travel speed, harvesting operation is faster and this results in lower fuel consumption as was observed during harvesting on the mounds.

\section{Economic Evaluation}

The total cost (variable and fixed) parameters of the mechanical yam harvester based on relevant assumptions is presented in Table 4 .

Table 4. Total cost of mechanical yam harvesting.

\begin{tabular}{|l|l|}
\hline Cost Parameter & Yam harvester \\
\hline Purchase price (US\$) & 1500 \\
\hline Salvage value (US\$) & 150 \\
\hline Economic life (years) & 10 \\
\hline Fixed Cost (US\$/y) & \\
\hline Depreciation & 135 \\
\hline Interest & 8.25 \\
\hline
\end{tabular}


C. K. Bosrotsi et al.

\begin{tabular}{|l|l|}
\hline \hline Insurance & 7.5 \\
\hline Tax & 0 \\
\hline Shelter & 7.5 \\
\hline Total Fixed Cost & 158.25 \\
\hline Fuel (Diesel) cost (US\$/L) & 0.91 \\
\hline Fuel Consumption (L/h) & 3.71 \\
\hline Field Capacity (ha/h) & 0.38 \\
\hline Working hours/y & 1000 \\
\hline Engine oil consumption (L/h) & 0.01 \\
\hline Lubricant cost (US\$/L) & 0.1365 \\
\hline Worker's salary (US\$) & 70 \\
\hline Number of Workers & 2 \\
\hline Variable cost (US\$/h) & \\
\hline Fuel & 3.38 \\
\hline Lubricant & 0.00 \\
\hline Repairs \& Maintenance & 0.08 \\
\hline Labour & 0.67 \\
\hline Total Variable Cost (US\$/h) & 4.13 \\
\hline Total Variable Cost (US\$/y) & 4126 \\
\hline TOTAL COST $(\mathbf{U S} / \mathbf{y})$ & $\mathbf{4 2 8 4}$ \\
\hline
\end{tabular}

The result shows that the total annual cost of the harvester is US4, 284.00.

Figure 10 shows the average total cost of yam production on either mounds or ridges for selected yam growing communities in Ghana as at November, 2016.

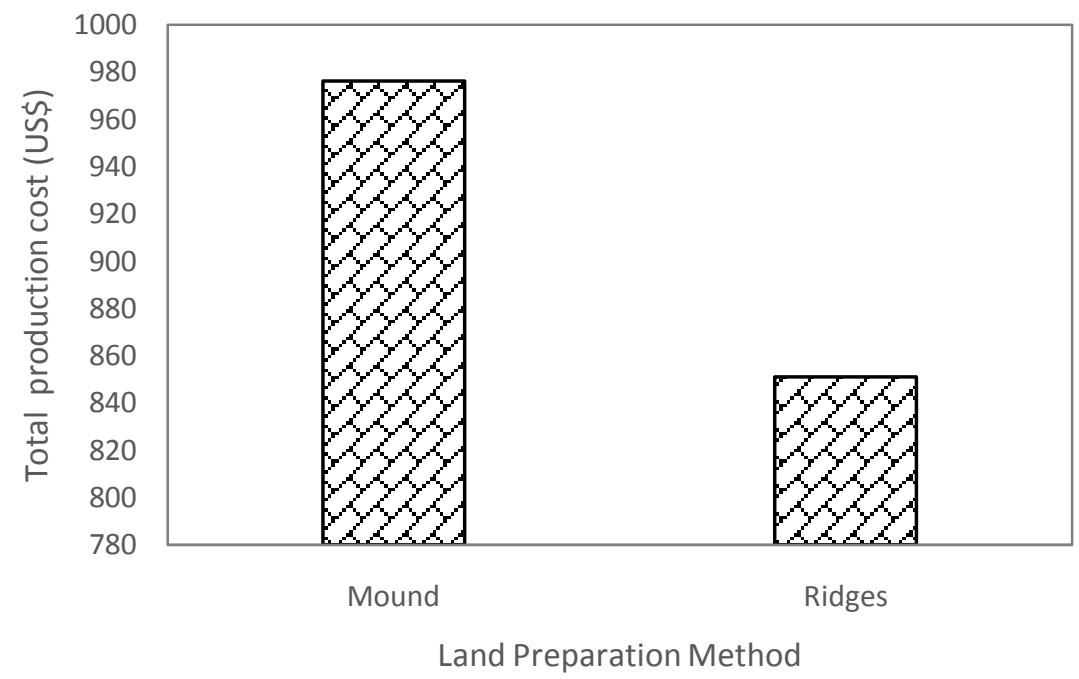

Figure 10. Total cost of yam production under mounding and ridging land preparation options.

The total cost of yam production under ridges was US\$ 851.00 whereas under the mounding option it was US $\$ 976.00$. This implies that the total production cost of yams using ridges was generally lower than that of mounds.

Table 5 shows the total cost of manual and mechanised harvesting on mounds and ridged land preparation methods as a percentage of total yam production cost.

Table 5. Total cost of manual and mechanised harvesting on mounds and ridged landforms as a percentage of total production cost.

\begin{tabular}{|l|l|l|}
\hline \multirow{2}{*}{ Land preparation method } & Harvesting method \\
\cline { 2 - 3 } & Manual & Mechanised \\
\hline Ridges & 14 & 7 \\
\hline Mounds & 12 & 6 \\
\hline
\end{tabular}

The results show that the total cost of mechanised yam harvesting was $50 \%$ less than that of the manual harvesting method under either the mound or ridged land preparation method.

Figure 11 shows the breakeven analysis chart for the mechanical yam harvester at a total fixed cost of US\$ 158.25 per annum, variable cost of US $\$ 4.13$ per $\mathrm{h}$ and machine hiring cost of US\$ 5.00 per $\mathrm{h}$. 


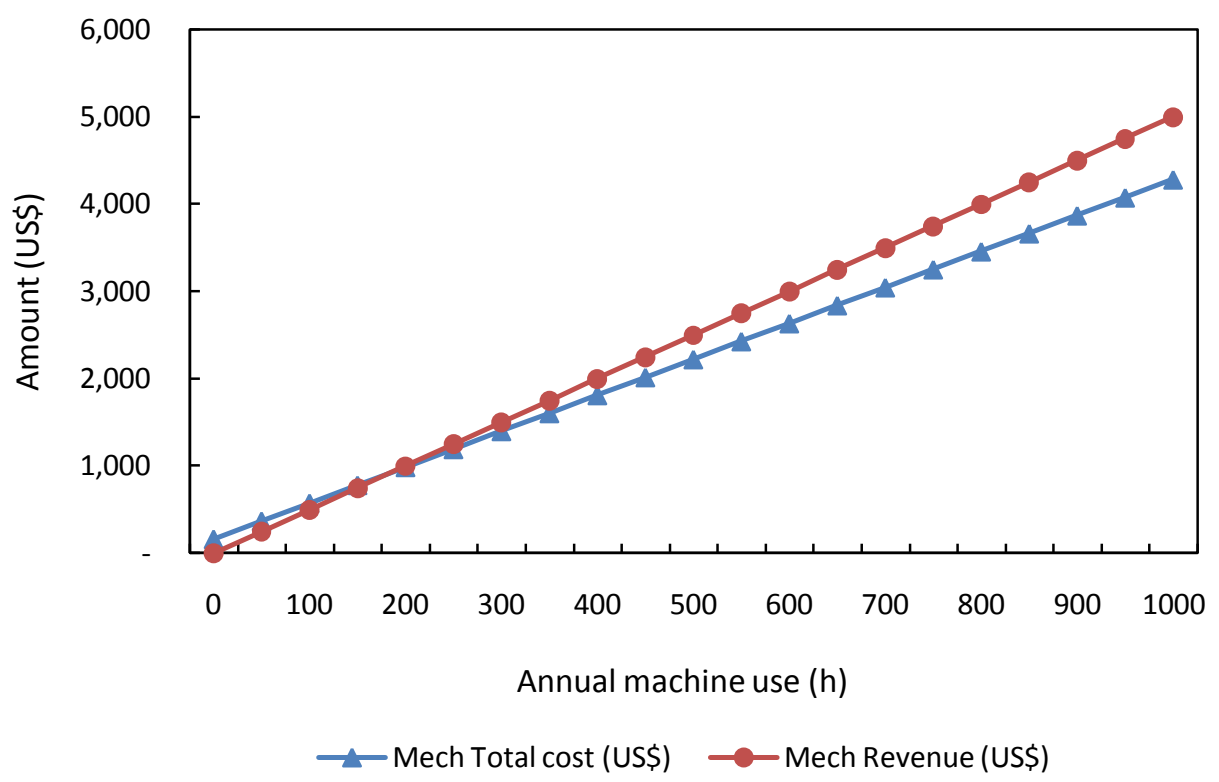

Figure 11. Breakeven analysis of using the mechanical yam harvester

The breakeven point for the hours of use of the mechanical yam harvester was $180 \mathrm{~h}$ which was equivalent to approximately 64 ha of yam field harvested. This implies that in a season the investment into a mechanical yam harvester for custom services can be recovered with substantial profit.

\section{CONCLUSIONS}

From the results of this study, the following conclusions can be made on the mechanical yam harvester:

1. The harvester performed satisfactorily on soils with minimal trash, moisture content ranged from $11.91 \%$ d.b to $14.48 \%$ d.b., bulk density ranged from $1.50 \mathrm{~g} / \mathrm{cm}^{3}$ to $1.62 \mathrm{~g} / \mathrm{cm}^{3}$, and cone penetration resistance of 0.41 to $1.33 \mathrm{MPa}$.

2. The harvester operated safely at an average soil depth range of $0.30-0.33 \mathrm{~m}$ and tuber depth of penetration ranging from 0.29 to $0.37 \mathrm{~cm}$. The tuber length from 0.33 to $0.38 \mathrm{~cm}$ and tuber damage ranged from $1.96 \%$ and $3.45 \%$ irrespective of yam variety.

3. Tractor harvesting speed ranged from 1.04 to $1.31 \mathrm{~m} / \mathrm{s}$ for ridged and mound landforms respectively whilst the field capacity ranged from 0.30 to $0.38 \mathrm{ha} / \mathrm{h}$ for ridged and mound landforms respectively. The fuel consumption ranged from 9.07 to 9.75 1/ha for mound and ridged landforms respectively whilst tractor wheel slip ranged from 2.93 to $3.79 \%$ for mound and ridged landforms respectively.

4. Mounding offered lower resistance to tractor movement coupled with reduced engine fuel consumption and lower tractor wheel slip though ridging was better at considerably reducing tuber damage during harvesting with the mechanical harvester, irrespective of yam variety harvested.

5. Ridging method of land preparation was generally better than mounding at reducing the total cost of production.

6. The use of the mechanical yam harvester was much better at reducing the total harvesting cost (approximately 50\% reduction) than manual harvesting options, irrespective of land preparation method. An added advantage of using the mechanical harvester was that the field was levelled after the harvesting operation. This offers an additional opportunity for immediate cropping.

7. With an investment of US\$ 1500.00 , the mechanical yam harvester at a fixed cost of US\$158.25 per annum and a variable cost of US\$4.13 per h, the breakeven point was $180 \mathrm{~h}$ of use (equivalent to 64 ha of field harvested) when hired for custom services at a cost of US\$ 5.00 per h.

8. The harvester is recommended for use by farmers to reduce drudgery to expedite yam harvesting operations. 


\section{REFERENCES}

[1] Aikins, S. H. M. and Haruna, K.. 2012. Tractor owners and operators perception about tractor breakdown causes at Tamale, Ghana.International Journal of Engineering Research and Technology, 1(8), 1-9.

[2] Akinbamowo, R. O., Ogunlowo, A. S. and Agbetoye, L. A. S., Development of a tractormounted cocoyam (Xanthosoma spp.) harvester. Australian Journal of Agricultural Engineering, 2(3), 82 .

[3] Amponsah, S. K., Bobobee, E. Y. H., Agyare, W. A., Okyere, J. B., Aveyire, J. and King, S. R. (2014). Mechanical cassava harvesting as influenced by seedbed preparation and cassava variety. Applied Engineering in Agriculture, 30(3), 391-403.

[4] Black C.A. 1965. "Methods of Soil Analysis: Part I Physical and mineralogical properties". American Society of Agronomy, Madison, Wisconsin, USA.

[5] Fairhurst, D. S. 2012. Using Excel for Business Analysis: A Guide to Financial Modelling Fundamentals. Wiley Publishing.

[6] FAOSTAT. 2013. FAO Statistical Yearbook. World Food and Agriculture. http://www.fao.org/ docrep/018/i3107e/i3107e00. htmAccessed: 30 January 2017.

[7] Hanna, M. 2001. Estimating Field Capacity of Field Machines. Cooperative Extension Service, Iowa State University of Science and Technology, PM 696(1-4).

[8] Hunt, D. R. 1983. Farm Power and Machinery Management. (8th ed.). Ames, USA:Iowa State University Press.

[9] Itodo, I. N. and Daudu, J. O. 2013. Performance evaluation of a tractor mounted yam harvester fitted with a collection unit. ASABE Meeting Presentation number 131592710, Kansas City, Missouri, July 21 - July 24, 2013. (doi: http://dx.doi.org/10.13031/aim.20131592710)

[10] Itodo, I. N. and Daudu, J. O. 2007. Performance evaluation of a yam (Dioscorea spp.) harvester. Agricultural Mechanization in Asia Africa And Latin America, 38(2), 79-83. 68

[11] Lindeburg, M. R. (1993). Engineering Economic Analysis: An Introduction. Belmont, CA: Professional Publications.

[12] Nweke, F. I. 2005. A Review of Cassava in Africa with Country Case Studies on Nigeria, Ghana, the United Republic of Tanzania, Uganda and Benin. FAO and IFAD.

[13] Opara, L. U. 2003. Yams: Post-Harvest Operation. INPhO Postharvest Compedium. Rome: Food and Agriculture Organization.http://www.fao.org/3/a-ax449e.pdf

[14] Otoo, E., Kleih, U., Boadu, P. and Amponsah, S. K. 2013. Ghana: In-depth value chain analysis Final Report. In Yam Improvement for Income and Food Security in West Africa (YIIFSWA) Project (p. 75).

[15] Sam, J. and Dapaah, H. 2009. Baseline survey report, West African Agricultural Productivity Programme (WAAPP), Ghana. Retrieved from http://waapp.coraf.org/ documents/WAAPP/ Rapports/Final WAAPP Baseline Survey Report Ghana.pdf

[16] Smith, D. W., Sims, B. G. and O'Neill, D. H. 1994. Testing and Evaluation of Agricultural Machinery and Equipment: Principles and Practices. Rome, Italy: Food and Agriculture Organization.

[17] Sowley, E. N. K. and Tiesaa, B. 2007. Survey on postharvest problems of yam in Northern Ghana - a case study of the Tolon-Kumbungu district. Ghana Journal of Horticulture, 6, 117121.

[18] VSN International. 2011. GenStat Discovery 3rd Edition. Hemel Hempstead, UK: VSN International. 